\title{
Activity of Cuban Plants Extracts against Leishmania amazonensis
}

\author{
Marley García, ${ }^{1}$ Lianet Monzote, ${ }^{1}$ Ramón Scull, ${ }^{2}$ and Pedro Herrera ${ }^{3}$ \\ ${ }^{1}$ Department of Parasitology, Institute of Tropical Medicine "Pedro Kourí," Apdo Postal No. 601, Havana 10400, Cuba \\ ${ }^{2}$ Department of Chemistry, Institute of Pharmacy and Food, University of Havana, Havana 10400, Cuba \\ ${ }^{3}$ Department of Systematic, Institute of Ecology and Systematic, Havana 10400, Cuba \\ Correspondence should be addressed to Marley García, marley@ipk.sld.cu \\ Received 14 November 2011; Accepted 4 January 2012 \\ Academic Editors: S. Tokuyama and T. B. Vree
}

Copyright (c) 2012 Marley García et al. This is an open access article distributed under the Creative Commons Attribution License, which permits unrestricted use, distribution, and reproduction in any medium, provided the original work is properly cited.

Natural products have long been providing important drug leads for infectious diseases. Leishmaniasis is a major health problem worldwide that affects millions of people especially in the developing nations. There is no immunoprophylaxis (vaccination) available for Leishmania infections, and conventional treatments are unsatisfactory; therefore, antileishmanial drugs are urgently needed. In this work, 48 alcoholic extracts from 46 Cuban plants were evaluated by an in vitro bioassay against Leishmania amazonensis. Furthermore, their toxicity was assayed against murine macrophage. The three most potent extracts against the amastigote stage of Leishmania amazonensis were from Hura crepitans, Bambusa vulgaris, and Simarouba glauca.

\section{Introduction}

Leishmaniasis is a protozoan parasitic disease found in 16 developed and 72 developing countries with 12 million cases [1]; it causes around 70000 deaths annually [2]. So far, no vaccine approved for human use is available [3]. Various antileishmanial agents are readily available in the market although none of these chemotherapy drugs are free from harmful side effects and toxicity [4-7]. Currently, the development of new drugs against leishmaniasis is a need.

The interest in plants products, specially in medicinal plants or their extracts, surfaced all over the world due to the belief that many herbal extracts have been extensively used by native populations to treat leishmaniasis $[8,9]$ and scientific reports have demonstrated their potential $[10,11]$. In the present study, the antileishmanial activity of 48 extracts from 46 Cuban plants was tested to validate the antiprotozoal properties of Cuban plants.

\section{Methods}

2.1. Plant Materials. Vegetative samples of 46 species were used, and their general data are presented in Table 1. All plants were collected and authenticated according to the
Cuban Flora by M. S. Ramón Scull and Dr. Pedro Herrera. Their voucher specimens or collector's numbers were assigned, and a sample was deposited in a herbarium (Table 1).

2.2. Preparation of Plant Extracts. The plant organs were dried in an oven with ventilation system at $30^{\circ} \mathrm{C}$ and crushed. The fluid extracts were prepared by maceration for seven days using $80 \%$ ethanol as solvent and 20\% water, according to the Regulation Norm 309 (Regulation Norm, 1992). Solvent was evaporated, and the extracts were lyophilized and dissolved in dimethyl-sulfoxide (DMSO, BDH, England) at $20 \mathrm{mg} / \mathrm{mL}$ and stored at $4^{\circ} \mathrm{C}$.

2.3. Reference Drug. Pentamidine (Richet, Buenos Aires, Argentina) was used as positive control and a stock solution prepared at a concentration of $10 \mathrm{mg} / \mathrm{mL}$.

2.4. Parasites. The MHOM/77BR/LTB0016 strain of Leishmania amazonensis was kindly provided by the Department of Immunology, Oswaldo Cruz Foundation (FIOCRUZ), Brazil. Parasites were routinely isolated by aspiration with needle from mouse lesions and maintained as promastigotes 
TABLE 1: List of plants used in this study and collections data.

\begin{tabular}{|c|c|c|c|c|c|}
\hline Plants species & Family & Part used & Collection date & Geographical areas & Voucher specimen \\
\hline Allium sativum $\mathrm{L}$. & Alliaceae & Leaves & 2006 & $\mathrm{NBG}^{\mathrm{a}}$, Havana & HAJB-HFC 87089 \\
\hline Aloe barbadensis L. & Asphodelaceae & Leaves & 2010 & "La Quiruvina," Artemisa & $\mathrm{HAC}^{\mathrm{d}} 42671$ \\
\hline Alternanthera sessilis (L.) R. Br. ex DC. & Amaranthaceae & Leaves & 2008 & IPF $^{\mathrm{b}}$, Havana & HAJB $^{\text {e }} 87100$ \\
\hline Annona glabra L. & Annonaceae & Leaves & 2006 & NBG, Havana & HAJB 8300098 \\
\hline Argemone mexicana L. & Papaveraceae & Leaves & 2009 & IPF & HAJB-HFC 87090 \\
\hline Artemisia absinthium L. & Asteraceae & Leaves & 2006 & NBG, Havana & HAJB 9700183 \\
\hline Artemisia vulgaris $\mathrm{L}$. & Asteraceae & Leaves & 2010 & "La Quiruvina," Artemisa & HAC 42673 \\
\hline Azadirachta indica A.Juss & Meliaceae & Leaves & 2008 & IPF $^{\mathrm{b}}$, Havana & HAJB-HFC 87099 \\
\hline Bambusa vulgaris Schrad. Ex J. C. Wendl. & Bambusinae & Leaves & 2006 & NBG, Havana & HAJB 9500087 \\
\hline Bambusa vulgaris Schrad. Ex J. C. Wendl. & Bambusinae & Root & 2010 & NBG, Havana & НАJB 9500087 \\
\hline Bidens pilosa $\mathrm{L}$. & Asteraceae & Leaves & 2006 & NBG, Havana & HAJB 9700169 \\
\hline Bursera simaruba (L.) Sarg. & Burseraceae & Leaves & 2006 & NBG, Havana & HAJB 8603305 \\
\hline Cajanus cajan (L.) Millsp. & Fabaceae & Leaves & 2010 & "La Quiruvina," Artemisa & HAJB-HFC 42670 \\
\hline Cassia grandis $\mathrm{L}$. & Leguminosae & Leaves & 2006 & NBG, Havana & HAJB 8300069 \\
\hline Cecropia peltata L. & Urticaceae & Leaves & 2010 & NBG, Havana & HAJB 8603239 \\
\hline Chenopodium ambrosioides L. & Chenopodiaceae & Leaves & 2010 & "La Quiruvina," Artemisa & $\mathrm{ROIG}^{\mathrm{e}} 4639$ \\
\hline Cissus sicyoides L. & Vitaceae & Leaves & 2010 & NBG, Havana & HAJB-HFC 87092 \\
\hline Citrus limetta Risso & Rutaceae & Leaves & 2006 & NBG, Havana & HAJB-HFC 87093 \\
\hline Cucurbita maxima Dutch. & Cucurbitaceae & Seeds & 2006 & NBG, Havana & HAJB-HFC 87091 \\
\hline Cupressus sempervirens L. & Cupressaceae & Leaves & 2006 & NBG, Havana & HAJB 8603788 \\
\hline Curcuma longa L. & Zingiberaceae & Rhizome & 2006 & NBG, Havana & НАJB 9700178 \\
\hline Cymbopogon citrate Stapf. & Poaceae & Leaves & 2006 & NBG, Havana & HAJB 8700008 \\
\hline Hura crepitans L. & Euphorbiaceae & Leaves & 2006 & NBG, Havana & НАJB 8600198 \\
\hline Indigofera suffruticosa Mill. & Fabaceae & Leaves & 2006 & NBG, Havana & НАJB 100079 \\
\hline Koanophyllon villosum (Sw.) King \& H. Rob. & Asteraceae & Leaves & 2010 & NBG, Havana & HAJB-HFC 87094 \\
\hline Lepidium virginicum $\mathrm{L}$. & Brassicaceae & Leaves & 2006 & NBG, Havana & HAJB 8700259 \\
\hline Luffa cylindrica L. & Cucurbitaceae & Leaves & 2006 & NBG, Havana & HAJB 8600366 \\
\hline Mangifera indica L. & Anacardiaceae & Leaves & 2006 & NBG, Havana & НАJB 9700183 \\
\hline Melaleuca leucadendron L. & Myrtaceae & Leaves & 2006 & NBG, Havana & HAJB 8501918 \\
\hline Melia azedarach L. & Meliaceae & Root & 2006 & NBG, Havana & HAJB 8402273 \\
\hline Momordica charantia L. & Cucurbitaceae & Leaves & 2008 & NBG, Havana & НАJB 9700180 \\
\hline Ocimum sanctum $\mathrm{L}$. & Lamiaceae & Leaves & 2006 & NBG, Havana & HAJB 9200485 \\
\hline Parthenium hysterophorus L. & Asteraceae & Leaves & 2006 & NBG, Havana & НАJB 9700175 \\
\hline Parthenium hysterophorus L. & Asteraceae & Root & 2010 & NBG, Havana & HAJB 9700176 \\
\hline Petiveria alliaceae $\mathrm{L}$. & Phytolaccaceae & Leaves & 2006 & NBG, Havana & HAJB 244 \\
\hline Picramnia pentandra Sw. & Simaroubaceae & Leaves & 2006 & NBG, Havana & HAJB 8303268 \\
\hline Punica granatum L. & Punicaceae & Fruit bark & 2006 & NBG, Havana & HAJB 8300050 \\
\hline Tradescantia discolor Sw. & Commelinaceae & Leaves & 2005 & NBG, Havana & HAJB 9200504 \\
\hline Roystonea regia (Kunth) O. F. Cook & Arecaceae & Leaves & 2010 & NBG, Havana & HFC 87098 \\
\hline Simarouba glauca DC. & Simaroubaceae & Leaves & 2006 & NBG, Havana & НАJB 8300710 \\
\hline Stachytarpheta jamaicensis (L.) Vahl & Simaroubaceae & Leaves & 2006 & NBG, Havana & HAJB 9200475 \\
\hline Tabernaemontana citrifolia $\mathrm{L}$. & Boraginaceae & Leaves & 2006 & NBG, Havana & HAJB 8500720 \\
\hline Tamarindus indica $\mathrm{L}$. & Apocynaceae & Stem bark & 2006 & NBG, Havana & HAJB 8300068 \\
\hline Thevetia peruviana L. & Caesalpiniaceae & Leaves & 2006 & NBG, Havana & HAJB-HFC 87095 \\
\hline Trichilia havanensis Jacq. & Meliaceae & Leaves & 2010 & NBG, Havana & HAJB-HFC 87097 \\
\hline Turnera ulmifolia L. & Turneraceae & Leaves & 2009 & NBG, Havana & HAJB 8602024 \\
\hline Zerumbet speciosum J. C. Wendl. & Zingiberaceae & Leaves & 2010 & NBG, Havana & HAJB-HFC 87096 \\
\hline
\end{tabular}

${ }^{a}$ NBG: the collection of plant was performed in the National Botanic Garden, Havana, Cuba.

${ }^{b}$ IPF: the collection of plant was performed in the Institute of Pharmacy and Food, Havana, Cuba.

'HFC: Herbarium of National Botanic Garden in the special series of Cuban Flora.

${ }^{\mathrm{d} H A C:}$ Herbarium of Systematic and Ecology Institute.

eHAJB: Herbarium of National Botanic Garden.

f ROIG: Herbarium of Experimental Station of Medicinal Plants "Dr. Juan Tomás Roig." 
at $26^{\circ} \mathrm{C}$ in Schneider's medium (Sigma-Aldrich, St. Louis, MO, USA) containing 10\% heat-inactivated fetal bovine serum (HFBS) (Sigma-Aldrich, St. Louis, MO, USA), $100 \mu \mathrm{g}$ of streptomycin/mL, and $100 \mathrm{U}$ of penicillin/mL, with passage each 3 or 4 days. The parasites were not used after 10 in vitro passages.

2.5. Antipromastigote Screening. Exponentially growing promastigotes $\left(10^{5}\right.$ promastigotes $\left./ \mathrm{mL}, 199 \mu \mathrm{L}\right)$ were plated in 96-well plates. Two microliters of extracts or $2 \mu \mathrm{L}$ of DMSO for control were added to the wells at a final concentration between 6.25 and $100 \mu \mathrm{g} / \mathrm{mL}$. Plates were incubated at $26^{\circ} \mathrm{C}$ for $72 \mathrm{~h}$. Then, 3-[4,5-dimethylthiazol-2-yl]-2,5diphenyltetrazolium bromide (MTT) (Sigma, St. Louis, MO, USA) solution $(15 \mu \mathrm{L})$ at $5 \mathrm{mg} / \mathrm{mL}$ dissolved in saline solution was added to each well. After incubation for additional $4 \mathrm{~h}$, the medium was removed and formazan crystals were dissolved by addition of $100 \mu \mathrm{L}$ of DMSO. Absorbance was determined using an EMS Reader MF Version 2.4-0, at a wavelength of $560 \mathrm{~nm}$ and $630 \mathrm{~nm}$ as reference $[12,13]$.

2.6. Cytotoxicity Assay. We determined the $\mathrm{IC}_{50}$ of the extracts on peritoneal macrophage from BALB/c mice. Resident macrophages were collected from peritoneal cavity of healthy BALB/c mice in RPMI 1640 medium (Sigma, St. Louis, Mo, USA) supplemented with antibiotics (penicillin $200 \mathrm{UI}$, streptomycin $200 \mu \mathrm{g} / \mathrm{mL}$ ), plated at $10^{6} / \mathrm{mL}$ in $96-$ well Lab-Tek (Costar, USA) and left to adhere for $2 \mathrm{~h}$ at $37^{\circ} \mathrm{C}$ in $5 \% \mathrm{CO}_{2}$. Nonadherent cells were removed by washing with saline solution after $2 \mathrm{~h}$ of incubation at $37^{\circ} \mathrm{C}$ in $5 \%$ $\mathrm{CO}_{2}$. Then, $198 \mu \mathrm{L}$ of medium with $10 \%$ of HFBS and antibiotics (penicillin $200 \mathrm{UI}$, streptomycin $200 \mu \mathrm{g} / \mathrm{mL}$ ) was added in each well, and later $2 \mu \mathrm{L}$ of extracts dilutions, previously prepared in medium, was added. Macrophages were treated with the extracts from 1.5 to $200 \mu \mathrm{g} / \mathrm{mL}$ for $72 \mathrm{~h}$. Cultures with DMSO were included as control treated. The cytotoxicity was determined using the colorimetric assay with MTT as described above in the promastigote assay [13].

2.7. Antiamastigote Activity. Peritoneal macrophages from $\mathrm{BALB} / \mathrm{c}$ mice were collected, plated at $10^{6} / \mathrm{mL}$ in 24 -well Lab-Tek (Costar, USA), and incubated $2 \mathrm{~h}$ at $37^{\circ} \mathrm{C}$ in $5 \%$ $\mathrm{CO}_{2}$. Nonadherent cells were removed, and stationary-phase L. amazonensis promastigotes were added at a $4: 1$ parasite/macrophage ratio. Cultures were added for further $4 \mathrm{~h}$, and cell monolayers were washed to remove free parasites. Then, $1990 \mu \mathrm{L}$ of the RPMI complete medium and $10 \mu \mathrm{L}$ of the different extracts were added, following serial dilutions $1: 2$, to obtain final concentrations between 12.5 and

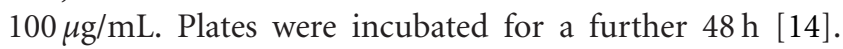
Cultures as control were included, which were treated with DMSO. Cultures were then fixed with absolute methanol, stained with Giemsa, and examined under light microscopy. The number of intracellular amastigotes was determined by counting the amastigotes resident in 100 macrophages per each sample. Results were expressed as percent of reduction of the infection rate (\% IR) in comparison with those obtained with positive controls. The infection rates were obtained by multiplying the percentage of infected macrophages by the number of amastigotes per infected macrophages [15].

2.8. Statistic Analysis. All tests were performed in triplicate, and the median inhibitory concentration $\left(\mathrm{IC}_{50}\right)$ to parasite and median cytotoxic concentration $\left(\mathrm{CC}_{50}\right)$ to peritoneal macrophage from $\mathrm{BALB} / \mathrm{c}$ mice were obtained directly from linear equation of dose-response curves. The results were expressed as their average and standard deviation.

The active extracts that showed an $\mathrm{IC}_{50}<100 \mu \mathrm{g} / \mathrm{mL}$ were selected as active against promastigote form, and cytotoxicity was determined. Then, the selectivity index (SI), calculated as ratio of $\mathrm{CC}_{50}$ for macrophage $/ \mathrm{IC}_{50}$ for promastigotes, was used to compare the toxicity and activity of the extracts. The extracts with an SI more than 5 were tested against the amastigote form. The extracts with an $\mathrm{IC}_{50} \leq 50 \mu \mathrm{g} / \mathrm{mL}$ were considered as active against intracellular amastigotes of Leishmania.

\section{Results}

The activity of extracts against $L$. amazonensis promastigotes, the cytoxicity against peritoneal macrophage from BALB/c mice, and the selectivity are shown in Table 2. Between them, 20 extracts showed activity, with an $\mathrm{IC}_{50}<100 \mu \mathrm{g} / \mathrm{mL}$, although only 4 extracts (Bambusa vulgaris, Hura crepitans, Mangifera indica, and Simarouba glauca) demonstrated selective activity against the parasite and were tested against intracellular amastigotes.

Among the four extracts evaluated against $L$. amazonensis amastigotes, three showed inhibition of growth with $\mathrm{IC}_{50} \leq$ $50 \mu \mathrm{g} / \mathrm{mL}$. The highest antileishmanial activity was exhibited by $H$. crepitans, with the lower $\mathrm{IC}_{50}$ value $(27.7 \pm 0.6 \mu \mathrm{g} / \mathrm{mL})$. The $\mathrm{IC}_{50}$ of $B$. vulgaris and $S$. glauca was $41.5 \pm 0.6 \mu \mathrm{g} / \mathrm{mL}$ and $45.5 \pm 0.3 \mu \mathrm{g} / \mathrm{mL}$, respectively. $M$. indica extract showed an $\mathrm{IC}_{50}$ value of $60.1 \pm 3.3 \mu \mathrm{g} / \mathrm{mL}$.

\section{Discussion}

Natural products are potential sources of new and selective agents for the treatment of important tropical diseases caused by protozoan and other parasites [16]. Only few laboratories are involved in drug evaluation and development against these devastating diseases, particularly against leishmaniasis, which has been considered as a "neglected disease" [17]. In this sense, the potential of plant products as a source of antileishmanial drugs has been demonstrated and considered as a promising approach. Several studies about screening of plants extracts against Leishmania have been reported [18-23].

Different models to evaluate drugs have been used, including promastigote, intracellular amastigote, or axenic amastigote forms of the parasite. The most important method is the counting of intracellular amastigotes, which are the clinical relevant stage of Leishmania in the mammalian host. Conventional procedures involve staining with Giemsa after treatment and manual counting. However, 
TABLE 2: Antileishmanial activity and cytotoxicity of Cuban plants extracts.

\begin{tabular}{|c|c|c|c|}
\hline Plants species & $\mathrm{IC}_{50}{ }^{\mathrm{a}} \pm \mathrm{SD}^{\mathrm{b}}(\mu \mathrm{g} / \mathrm{mL})$ & $\mathrm{CC}_{50}{ }^{\mathrm{c}} \pm \mathrm{SD}(\mu \mathrm{g} / \mathrm{mL})$ & $\mathrm{SI}^{\mathrm{d}}$ \\
\hline A. sativum & $153.2 \pm 2.1$ & - & - \\
\hline A. barbadensis & $77.5 \pm 0.9$ & $150.3 \pm 3.4$ & 2 \\
\hline A. sessilis & $>200$ & - & - \\
\hline A. glabra & $37.8 \pm 0.1$ & - & - \\
\hline A. mexicana & $>200$ & - & - \\
\hline A. absinthium & $129.0 \pm 1.5$ & - & - \\
\hline A. vulgaris & $55.0 \pm 3.2$ & $107.7 \pm 5.1$ & 2 \\
\hline A. indica & $>200$ & - & 一 \\
\hline B. vulgaris (leaves) & $60.5 \pm 7.3$ & $276.5 \pm 1.2$ & 5 \\
\hline B. vulgaris (root) & $191.6 \pm 1.1$ & - & 一 \\
\hline B. pilosa & $73.7 \pm 0.1$ & $222.8 \pm 1.1$ & 3 \\
\hline B. simaruba & $163.3 \pm 1.8$ & & \\
\hline C. cajan & $51.7 \pm 0.7$ & $132.5 \pm 5.7$ & 3 \\
\hline C. grandis & $>200$ & - & - \\
\hline C. peltata & $>200$ & - & 一 \\
\hline C. ambrosioides & $>200$ & - & - \\
\hline C. sicyoides & $>200$ & - & 一 \\
\hline C. limetta & $73.6 \pm 1.3$ & $210.6 \pm 3.9$ & 3 \\
\hline C. maxima & $62.2 \pm 0.1$ & $161.7 \pm 0.9$ & 3 \\
\hline C. sempervirens & $>200$ & - & 一 \\
\hline C. longa & $>200$ & - & 一 \\
\hline C. citrate & $>200$ & - & 一 \\
\hline H. crepitans & $16.4 \pm 2.1$ & $390.5 \pm 8.6$ & 24 \\
\hline I. suffruticosa & $75.8 \pm 4.5$ & $158.5 \pm 6.2$ & 2 \\
\hline K. villosum & $>200$ & - & 一 \\
\hline L. virginicum & $109.7 \pm 1.8$ & - & - \\
\hline L. cylindrica & $127.9 \pm 1.0$ & - & 一 \\
\hline M. indica & $51.2 \pm 0.1$ & $442.4 \pm 2.9$ & 9 \\
\hline M. leucadendron & $57.2 \pm 2.9$ & $199.2 \pm 4.7$ & 3 \\
\hline M. azedarach & $168.6 \pm 1.9$ & - & 一 \\
\hline M. charantia & $59.8 \pm 0.4$ & $26.7 \pm 0.3$ & 0 \\
\hline O. sanctum & $96.9 \pm 0.1$ & $216.9 \pm 4.8$ & 2 \\
\hline P. hysterophorus (leaves) & $54.7 \pm 1.2$ & $89.2 \pm 1.5$ & 0 \\
\hline P. hysterophorus (root) & $46.9 \pm 1.7$ & $140.2 \pm 0.2$ & 3 \\
\hline P. alliaceae & $151.5 \pm 4.1$ & - & 一 \\
\hline P. pentandra & $140.8 \pm 1.4$ & - & 一 \\
\hline P. oleracea & $63.9 \pm 2.6$ & $125.9 \pm 1.9$ & 2 \\
\hline P. granatum & $39.4 \pm 8.8$ & $129.0 \pm 4.6$ & 3 \\
\hline R. spathacea & $71.4 \pm 1.4$ & $244.6 \pm 1.6$ & 3 \\
\hline R. regia & $>200$ & - & 一 \\
\hline S. glauca & $47.5 \pm 0$ & $228.7 \pm 8.0$ & 5 \\
\hline S. jamaicensis & $111.8 \pm 1.2$ & - & 一 \\
\hline T. citrifolia & $>200$ & - & 一 \\
\hline T. indica & $>200$ & - & 一 \\
\hline T. peruviana & $>200$ & - & - \\
\hline T. havanensis & $>200$ & - & - \\
\hline T. ulmifolia & $>200$ & - & - \\
\hline Z. speciosum & $133.1 \pm 0.8$ & - & - \\
\hline Pentamidine & $0.37 \pm 0.01$ & $11.7 \pm 1.7$ & 32 \\
\hline
\end{tabular}

${ }^{\mathrm{a}} \mathrm{IC}_{50}$ : concentration of drug that caused $50 \%$ of growth inhibition of promastigotes of L. amazonensis.

bSD: standard deviation.

${ }^{\mathrm{c}} \mathrm{CC}_{50}$ : concentration of drug that caused $50 \%$ of mortality of peritoneal macrophage from BALB/c.

${ }^{\mathrm{d}} \mathrm{SI}$ : selectivity index. Bold data indicate the extract selected. 
this conventional procedure has limitations such as being time consuming, the use of animals for extraction of macrophages, and the possible error in the counting. Axenic amastigotes forms have been developed to obtain a more simple and reproducible method. These are technically easier and less expensive and require a very shorter time for execution. However, this model lacks information about the behavior of macrophages during the treatment, their possible influence on drug activity, or possible damage received due to toxicity [24]. Alternatively, the promastigote form has been used in screening investigations. Although it is not a clinical relevant stage, it was reported that this parasitic form gives information on specific antileishmanial activity respect to toxicity showed (selectivity of the product). In addition, the tests are easy and highly reproducible [22]. The use of the promastigote form has been widely demonstrated as the preliminary test in screening of plant extract $[8,25,26]$.

As part of a screening project of natural plants against protozoan parasites, we tested 48 extracts against Leishmania, which were selected according to the previous literature that mentioned these plants with antiparasitic properties [27]. In addition, the evaluated plants present an easy cultivation and can be obtained in high quantities of samples.

Cuba presents a rich plant population that has been unexploited in the field of antiprotozoals. Nevertheless, previous studies about antileishmanial potentialities of Cuban plants were reported, including Chenopodium ambrosioides [28], Piper auritum [29], and Bidens pilosa [23]. We found that $42 \%$ (20 extracts) of the tested products showed leishmanicidal activity with an $\mathrm{IC}_{50} \leq 100 \mu \mathrm{g} / \mathrm{mL}$ against promastigotes, of which only $20 \%$ (4 extracts) exhibited selectivity (SI > 5) and of them 75\% (3 extracts) caused growth inhibition in the antiamastigote assay.

Among the plant species evaluated here, $H$. crepitans caused the higher inhibition of promastigotes growth $\left(\mathrm{IC}_{50}=\right.$ $16.4 \mu \mathrm{g} / \mathrm{mL})$ and lower toxicity against host cell $\left(\mathrm{IC}_{50}=\right.$ $390.5 \mu \mathrm{g} / \mathrm{mL}$ ), with an $\mathrm{SI}=24$. This plant showed the highest activity with an $\mathrm{IC}_{50}=27.7 \mu \mathrm{g} / \mathrm{mL}$ against the amastigote form. The results demonstrated the presence of compounds with reasonable potency. $H$. crepitans is a native plant from tropical America that has been used for amoebiasis treatment [30] and against other protozoa such as Plasmodium falciparum [31]. In Nicaragua, this plant is used to treat helmintic diseases as ascariasis [30] and in Loreto, Peru, is used by the population to treat the leishmaniasis [8] with acceptable efficacy. In addition, this extract has shown promising activity against $P$. falciparum [32], with a low toxicity and a SI $>10$. In the literature uses of its seeds are reported as emmenagogue although they can cause toxic effects, including the death of patients [33]. The toxicity of this plant is caused by two toxic albumins (toxalbumins), hurina and crepitina, which are distributed among all plant organs $[34,35]$.

On the other hand, the leaves extract from $B$. vulgaris showed an $\mathrm{IC}_{50}=60.49 \mu \mathrm{g} / \mathrm{mL}$ against the promastigote form and $\mathrm{SI}=5$, while the activity was better against the amastigote form, with an $\mathrm{IC}_{50}=41.5 \mu \mathrm{g} / \mathrm{mL}$. However the root extract of this species did not show antileishmanial activity, which would be due to the differential distribution of metabolites in the plant. This finding should indicate that the component(s) responsible for leishmanicidal activity is (are) found in a major percent in the leaves, resulting in the parasite inhibition presented. B. vulgaris is an original tropical plant from Old World that has been cultivated in America [27]. Previously, it has been reported that $B$. vulgaris leave extract was inactive in a different screening approach because the extract was dissolved in ethanol [23]. This demonstrates the importance of the dissolvent in the screening approaches. DMSO is a membrane permeabiliser and is known for its ability to serve as carried to transport the drugs into cells [36]. Additionally, this extract has shown activity against other protozoa, such as $P$. falciparum [32]. Other uses include antiparasitic preventive control for dogs [37], cuts, injuries, and swellings [38] and as diuretic in the east population of Cuba [27]. Chemical analysis of $B$. vulgaris leave extract revealed the presence of different bioactive components, including: alkaloids, tannins, phenolics, glycosides, saponins, flavonoids, and anthraquinones [39] S. glauca also showed a promising antileishmanial activity. The $\mathrm{IC}_{50}$ against promastigotes was similar to that against amastigotes ( $\mathrm{IC}_{50}$ of 47.5 and $45.5 \mu \mathrm{g} / \mathrm{mL}$, resp.) and an SI of 5 was obtained. This plant is present in Latin America and has been used for different purposes, for example, in Cuba as emmenagogue, febrifuge, antidysenteric, antihelmintic, and antiherpetic [27], in Haití for the cutaneous lesions [40], and in Guatemala against malaria and amoebiasis [41]. The glaucarrubin is a terpenoids, present in this plant, has been described as responsible for the activity against Grampositive bacteria and protozoa parasite, specially Entoameba histolytica and P. falciparum [40].

Several reports in the literature have shown the antileishmanial activity of some plant extracts, including the hidroalcoholic extract from C. ambrosioides [42] and Ocimum sanctum [43]. However, we did not observe antileishmanial activity of these plants in this study. This apparent controversial result can be due to the variation of chemical components between plants from different geographic areas, which have been documented [44], including plants from the same country [9].

\section{Conclusion}

In sum, in this study, 48 Cuban plants extracts were evaluated against $L$. amazonensis. The extracts of $H$. crepitans, $B$. vulgaris, and S. glauca showed promising antileishmanial activity against life cycle stages of the parasite and high selectivity compared with the activity against mouse peritoneal macrophages. For this reason the next step should be the purification and identification of the active principles of these plants.

\section{Acknowledgment}

Thanks are due to National Botanic Garden for their cooperation, especially to M. S. Reinier Morejón for helpful advice. 


\section{References}

[1] F. Chappuis, S. Sundar, A. Hailu et al., "Visceral leishmaniasis: what are the needs for diagnosis, treatment and control?" Nature Reviews Microbiology, vol. 5, no. 11, pp. 873-882, 2007.

[2] J. Guillon, I. Forfar, M. Mamani-Matsuda et al., "Synthesis, analytical behaviour and biological evaluation of new 4-substituted pyrrolo[1,2-a] quinoxalines as antileishmanial agents," Bioorganic and Medicinal Chemistry, vol. 15, no. 1, pp. 194210, 2007.

[3] R. N. Coler and S. G. Reed, "Second-generation vaccines against leishmaniasis," Trends in Parasitology, vol. 21, no. 5, pp. 244-249, 2005.

[4] L. Kedzierski, A. Sakthianandeswaren, J. M. Curtis, P. C. Andrews, P. C. Junk, and K. Kedzierska, "Leishmaniasis: current treatment and prospects for new drugs and vaccines," Current Medicinal Chemistry, vol. 16, no. 5, pp. 599-614, 2009.

[5] P. R. Veera, V. Vobalaboina, and N. Ali, "Antileishmanial activity, pharmacokinetics and tissue distribution studies of mannose-grafted amphotericin B lipid nanospheres," Journal of Drug Targeting, vol. 17, no. 2, pp. 140-147, 2009.

[6] H. W. Murray, "Clinical and experimental advances in treatment of visceral leishmaniasis," Antimicrobial Agents and Chemotherapy, vol. 45, no. 8, pp. 2185-2197, 2001.

[7] B. Klllingley, L. E. M. Lamb, and R. N. Davidson, "Miltefosine to treat cutaneous leishmaniasis caused by Leishmania tropica," Annals of Tropical Medicine and Parasitology, vol. 103, no. 2, pp. 171-175, 2009.

[8] L. P. Kvist, S. B. Christensen, H. B. Rasmussen, K. Mejia, and A. Gonzalez, "Identification and evaluation of Peruvian plants used to treat malaria and leishmaniasis," Journal of Ethnopharmacology, vol. 106, no. 3, pp. 390-402, 2006.

[9] M. J. Chan-Bacab, E. Balanza, E. Deharo, V. Muñoz, R. D. García, and L. M. Peña-Rodríguez, "Variation of leishmanicidal activity in four populations of Urechites andrieuxii," Journal of Ethnopharmacology, vol. 86, no. 2-3, pp. 243-247, 2003.

[10] L. G. Rocha, J. R. G. S. Almeida, R. O. Macêdo, and J. M. Barbosa-Filho, "A review of natural products with antileishmanial activity," Phytomedicine, vol. 12, no. 6-7, pp. 514-535, 2005.

[11] S. Gupta, B. Raychaudhuri, S. Banerjee, B. Das, S. Mukhopadhaya, and S. C. Datta, "Momordicatin purified from fruits of Momordica charantia is effective to act as a potent antileishmania agent," Parasitology International, vol. 59, no. 2, pp. 192-197, 2010.

[12] A. Dutta, S. Bandyopadhyay, C. Mandal, and M. Chatterjee, "Development of a modified MTT assay for screening antimonial resistant field isolates of Indian visceral leishmaniasis," Parasitology International, vol. 54, no. 2, pp. 119-122, 2005.

[13] D. Sladowski, S. J. Steer, R. H. Clothier, and M. Balls, "An improved MTT assay," Journal of Immunological Methods, vol. 157, no. 1-2, pp. 203-207, 1993.

[14] E. C. Torres-Santos, D. L. Moreira, M. A. C. Kaplan, M. N. Meirelles, and B. Rossi-Bergmann, "Selective effect of 2,6'dihydroxy-4'-methoxychalcone isolated from Piper aduncum on Leishmania amazonensis," Antimicrobial Agents and Chemotherapy, vol. 43, no. 5, pp. 1234-1241, 1999.

[15] J. C. Delorenzi, M. Attias, C. R. Gattass et al., "Antileishmanial activity of an indole alkaloid from Peschiera australis," Antimicrobial Agents and Chemotherapy, vol. 45, no. 5, pp. 13491354, 2001.

[16] C. W. Wright and J. D. Phillipson, "Natural products and the development of selective antiprotozoal drugs," Phytotherapy Research, vol. 4, no. 4, pp. 127-139, 1990.
[17] P. J. Hotez, M. E. Bottazzi, C. Franco-Paredes, S. K. Ault, and M. R. Periago, "The neglected tropical diseases of Latin America and the Caribbean: a review of disease burden and distribution and a roadmap for control and elimination," PLoS Neglected Tropical Diseases, vol. 2, no. 9, article e300, 2008.

[18] M. S. Gachet, J. S. Lecaro, M. Kaiser et al., "Assessment of antiprotozoal activity of plants traditionally used in Ecuador in the treatment of leishmaniasis," Journal of Ethnopharmacology, vol. 128, no. 1, pp. 184-197, 2010.

[19] E. Abdel-Sattar, L. Maes, and M. M. Salama, "In vitro activities of plant extracts from Saudi Arabia against malaria, leishmaniasis, sleeping sickness and Chagas disease," Phytotherapy Research, vol. 24, no. 9, pp. 1322-1328, 2010.

[20] J. El-On, L. Ozer, J. Gopas et al., "Antileishmanial activity in Israeli plants," Annals of Tropical Medicine and Parasitology, vol. 103, no. 4, pp. 297-306, 2009.

[21] V. Céline, P. Adriana, D. Eric et al., "Medicinal plants from the Yanesha (Peru): evaluation of the leishmanicidal and antimalarial activity of selected extracts," Journal of Ethnopharmacology, vol. 123, no. 3, pp. 413-422, 2009.

[22] Y. Estevez, D. Castillo, M. T. Pisango et al., "Evaluation of the leishmanicidal activity of plants used by Peruvian Chayahuita ethnic group," Journal of Ethnopharmacology, vol. 114, no. 2, pp. 254-259, 2007.

[23] M. García, L. Monzote, A. M. Montalvo, and R. Scull, "Screening of medicinal plants against Leishmania amazonensis," Pharmaceutical Biology, vol. 48, no. 9, pp. 1053-1058, 2010.

[24] D. Sereno and J. L. Lemesre, "Axenically cultured amastigote forms as an in vitro model for investigation of antileishmanial agents," Antimicrobial Agents and Chemotherapy, vol. 41, no. 5, pp. 972-976, 1997.

[25] S. R. Peraza-Sánchez, F. Cen-Pacheco, A. Noh-Chimal et al., "Leishmanicidal evaluation of extracts from native plants of the Yucatan peninsula," Fitoterapia, vol. 78, no. 4, pp. 315-318, 2007.

[26] A. G. Tempone, P. Sartorelli, D. Teixeira et al., "Brazilian flora extracts as source of novel antileishmanial and antifungal compounds," Memorias do Instituto Oswaldo Cruz, vol. 103, no. 5, pp. 443-449, 2008.

[27] J. T. Roig, Plantas Medicinales, Aromáticas o Venenosas de Cuba, Editorial Científico-Técnica, La Habana, Cuba, 2 edition, 1974.

[28] L. Monzote, A. M. Montalvo, S. Almanonni, R. Scull, M. Miranda, and J. Abreu, "Activity of the essential oil from Chenopodium ambrosioides grown in Cuba against Leishmania amazonensis," Chemotherapy, vol. 52, no. 3, pp. 130-136, 2006.

[29] L. Monzote, M. García, A. M. Montalvo, R. Scull, and M. Miranda, "Chemistry, cytotoxicity and antileishmanial activity of the essential oil from Piper auritum," Memorias do Instituto Oswaldo Cruz, vol. 105, no. 2, pp. 168-173, 2010.

[30] J. A. López-Sáez and J. Pérez-Soto, "Etnobotánica medicinal y parasitosis intestinales en la isla de Ometepe, Nicaragua," Polibotánica, vol. 30, pp. 137-161, 2010.

[31] V. Muñoz, M. Sauvain, G. Bourdy et al., "A search for natural bioactive compounds in Bolivia through a multidisciplinary approach. Part III. Evaluation of the antimalarial activity of plants used by Altenos Indians," Journal of Ethnopharmacology, vol. 71, no. 1-2, pp. 123-131, 2000.

[32] A. F.-C. Valdés, J. M. Martínez, R. S. Lizama, Y. G. Gaitén, D. A. Rodríguez, and J. A. Payrol, "In vitro antimalarial activity and cytotoxicity of some selected cuban medicinal plants," Revista do Instituto de Medicina Tropical de Sao Paulo, vol. 52, no. 4, pp. 197-201, 2010. 
[33] J. A. Arlington, Cabrits Plants and Their Uses, Ministry of Agriculture, Forestry and Wildlife Division, Roseau, Dominica, 1986.

[34] W. G. Jaffe, "Hurain, a new plant protease from Hura crepitans," The Journal of Biological Chemistry, vol. 149, pp. 1-7, 1943.

[35] W. G. Jaffé and D. Seidl, "Crepitin, a phytohemagglutinin from Hura crepitans," Experientia, vol. 25, no. 8, pp. 891-892, 1963.

[36] V. I. Gordeliy, M. A. Kiselev, P. Lesieur, A. V. Pole, and J. Teixeira, "Lipid membrane structure and interactions in dimethyl sulfoxide/water mixtures," Biophysical Journal, vol. 75, no. 5, pp. 2343-2351, 1998.

[37] C. Lans, T. Harper, K. Georges, and E. Bridgewater, "Medicinal plants used for dogs in Trinidad and Tobago," Preventive Veterinary Medicine, vol. 45, no. 3-4, pp. 201-220, 2000.

[38] C. Lans, "Comparison of plants used for skin and stomach problems in Trinidad and Tobago with Asian ethnomedicine," Journal of Ethnobiology and Ethnomedicine, vol. 3, article 3, 2007.

[39] M. T. Yakubu and B. B. Bukoye, "Abortifacient potentials of the aqueous extract of Bambusa vulgaris leaves in pregnant Dutch rabbits," Contraception, vol. 80, no. 3, pp. 308-313, 2009.

[40] A. Cáceres, Plantas de Uso Medicinal en Guatemala, Colección Monografias, Editorial Universitaria, Guatemala, 1996.

[41] Seminario Tramil 7, Hacia una Farmacopea Caribeña. Investigación Científica y Uso Popular de las Plantas Medicinales en el Caribe, Ediciones Emile Désormeaux, Santo Domingo, Dominican Republic, 1995.

[42] F. J. Patrício, G. C. Costa, P. V. S. Pereira et al., "Efficacy of the intralesional treatment with Chenopodium ambrosioides in the murine infection by Leishmania amazonensis," Journal of Ethnopharmacology, vol. 115, no. 2, pp. 313-319, 2008.

[43] V. D. Zheljazkov, C. L. Cantrell, B. Tekwani, and S. I. Khan, "Content, composition, and bioactivity of the essential oils of three basil genotypes as a function of harvesting," Journal of Agricultural and Food Chemistry, vol. 56, no. 2, pp. 380-385, 2008.

[44] N. D. Yuliana, A. Khatib, Y. H. Choi, and R. Verpoorte, "Metabolomics for bioactivity assessment of natural products," Phytotherapy Research, vol. 25, no. 2, pp. 157-169, 2011. 

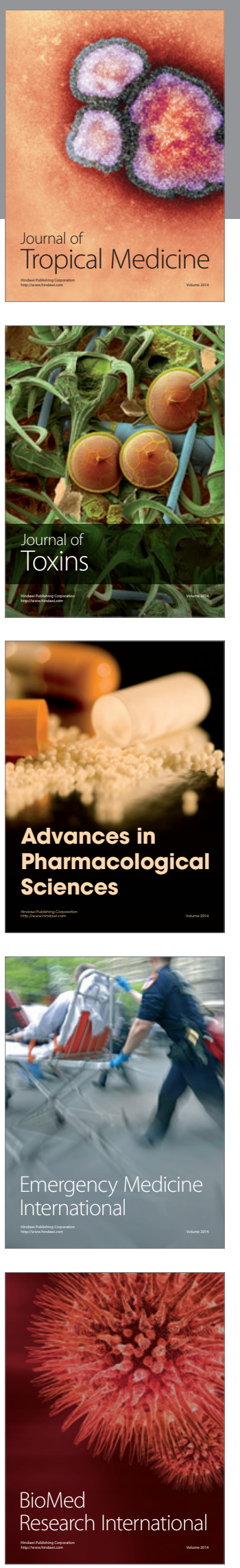
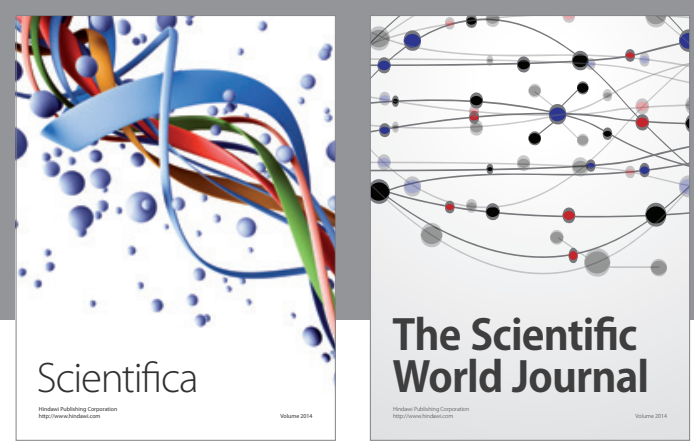

The Scientific World Journal
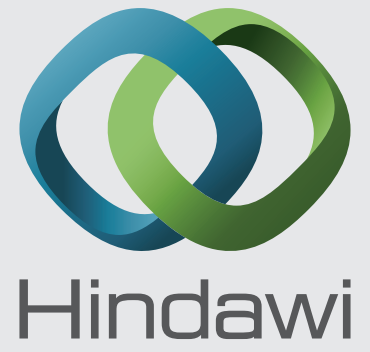

Submit your manuscripts at

http://www.hindawi.com
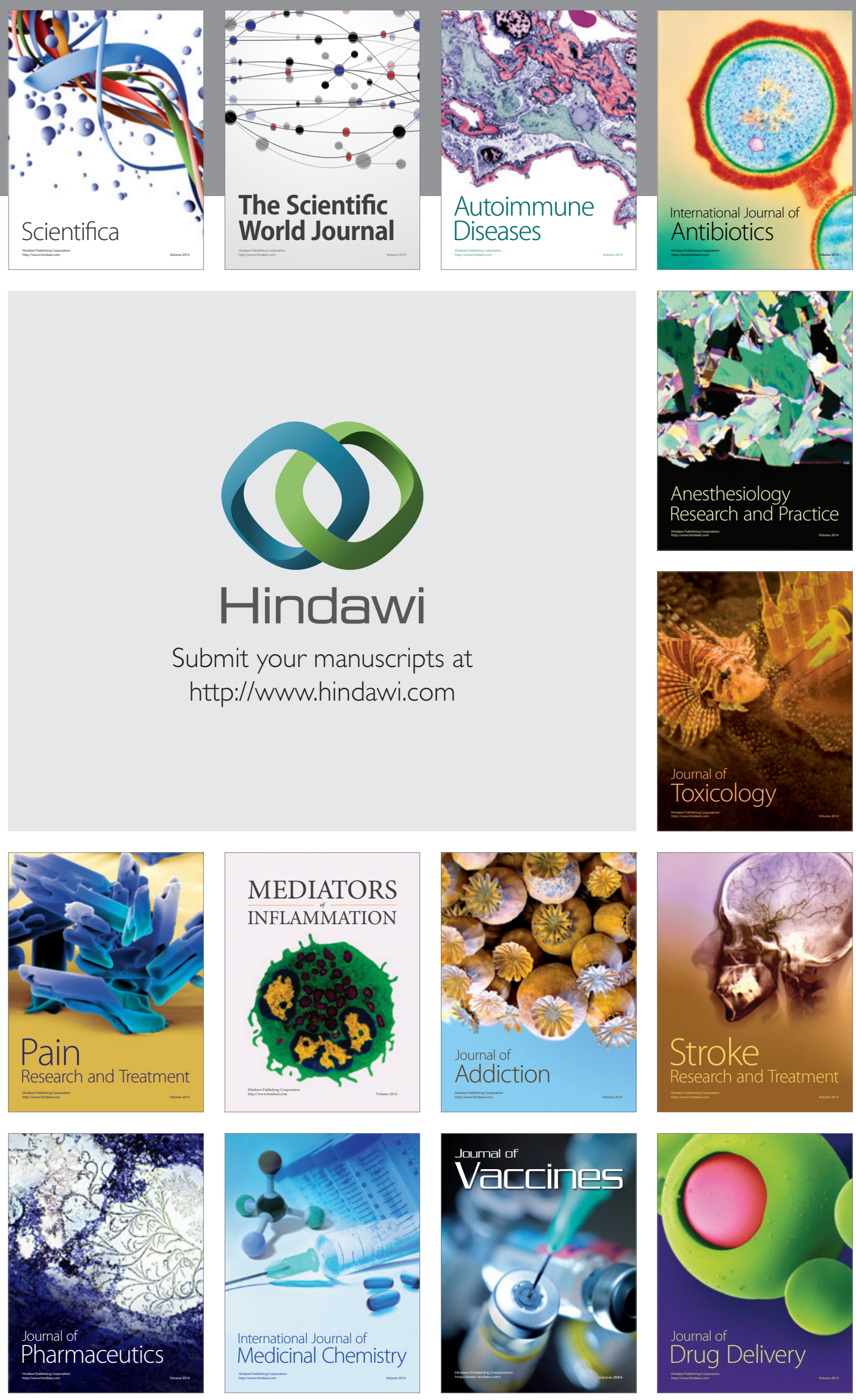